\title{
Release of dissolved organic nitrogen by size-fractionated natural planktonic assemblages in coastal waters
}

\author{
Toru Hasegawa ${ }^{1, *}$, Isao Koike ${ }^{1}$, Hiroshi Mukai ${ }^{2}$ \\ 'Ocean Research Institute, University of Tokyo, 1-15-1, Minamidai, Nakano, Tokyo 164-8639, Japan \\ ${ }^{2}$ Akkeshi Marine Biological Station, Hokkaido University Akkeshi, Hokkaido 088-1113, Japan
}

\begin{abstract}
To evaluate the effect of differences in community structure on the process of dissolved organic nitrogen (DON) release in natural planktonic assemblages, $\mathrm{DO}^{15} \mathrm{~N}$ release from size-fractionated $(<20$ and $<94 \mu \mathrm{m})$ waters of Akkeshi Bay, eastern Hokkaido, Japan, was measured after the addition of ${ }^{15} \mathrm{NH}_{4}{ }^{+}$. Calculations of percent extracellular release (PER) based on particulate organic ${ }^{15} \mathrm{~N}$-nitrogen $\left(\mathrm{PO}^{15} \mathrm{~N}\right)$ and $\mathrm{DO}{ }^{15} \mathrm{~N}$ accumulation were higher in the $<20 \mu \mathrm{m}$ fraction than in the $<94 \mu \mathrm{m}$ fractions in 2 out of 3 experiments; though the absolute magnitude of the release was higher in the larger size-fraction. Phytoplankton was primarily responsible for the $D O^{15} \mathrm{~N}$ release in the $<20 \mu \mathrm{m}$ fraction, which suggested more efficient DON release by smaller phytoplankton compared to larger ones. A passive permeation through the cell membrane is a likely explanation for the DON release observed in our study. PER $(<94 \mu \mathrm{m})$ fell within the range of 2.7 to $4.9 \%$, which is almost equal to, or somewhat lower than, the PER reported for carbon. In addition, the occurrence of tight coupling between DON release and its consumption by bacteria was suggested in a time-course experiment, showing efficient use of released nitrogenous compounds within the natural community.
\end{abstract}

KEY WORDS: DON $\cdot$ Phytoplankton · Size-fraction $\cdot{ }^{15} \mathrm{~N}$ tracer

\section{INTRODUCTION}

Dissolved organic nitrogen (DON) is often the largest pool of combined nitrogen in marine environments (Sharp 1983), and previous studies suggest that DON is a potentially important nitrogen source for bacteria and phytoplankton populations (Jackson \& Williams 1985, Tupas \& Koike 1991, Bronk \& Glibert 1993a). Evaluation of DON dynamics in the upper ocean, however, has been hampered by the nature of DON, such as the complexity of its composition and high background concentrations.

In a planktonic community, organic compounds including DON originate from primary production. There are many possible mechanisms attributed to DON release, which include direct release by phytoplankton (Mague et al. 1980), excretion by hetero-

•E-mail: thasegaw@ori.u-tokyo.ac.jp trophs (Nagata \& Kirchman 1991, Strom et al. 1997), sloppy feeding by zooplankton (Lampert 1978, Strom et al. 1997) and lysis by virus infection (Bratbak et al. 1992).

Recently, reliable methods for determining the ${ }^{15} \mathrm{~N}$ content of DON have been developed (Axler \& Reuter 1986, Bronk \& Glibert 1991, Slawyk \& Raimbault 1995, Bronk \& Ward 1999). The application of $\mathrm{DO}^{15} \mathrm{~N}$ determination has revealed that ${ }^{15} \mathrm{NH}_{4}{ }^{+}$assimilated by a planktonic population was released as $\mathrm{DO}^{15} \mathrm{~N}$ within a few hours, and that this $D{ }^{15} \mathrm{~N}$ was utilized by bacteria and/or phytoplankton (Axler \& Reuter 1986, Bronk \& Glibert 1991, 1993a,b, Slawyk \& Raimbault 1995). Bronk \& Glibert (1993b) suggested the importance of direct DON release by phytoplankton and DON release mediated by micrograzers. However, our understanding of biological and environmental factors controlling the DON dynamics is still limited.

In this study, we employed size-fractionated incubations $(<20$ and $<94 \mu \mathrm{m})$ with ${ }^{15} \mathrm{NH}_{4}{ }^{+}$to evaluate the 
effect of differences in community structure on the process of $D \mathrm{O}^{15} \mathrm{~N}$ release in coastal waters. Based on the accumulations of particulate organic ${ }^{15} \mathrm{~N}$-nitrogen $\left(\mathrm{PO}^{15} \mathrm{~N}\right)$ and $\mathrm{DO}^{15} \mathrm{~N}$ during the size-fractionated incubation, it was suggested that smaller phytoplankton release $\mathrm{DO}^{15} \mathrm{~N}$ more efficiently than larger ones and that a possible mechanism of direct release by phytoplankton is passive permeation.

\section{MATERIAL AND METHODS}

Incubation experiments. Incubation experiments were performed on 25 May, 29, 30 June and 24 August, 1998. In the morning, surface seawater was collected in $20 \mathrm{l}$ carboys at a station (water depth, $13 \mathrm{~m}: 43^{\circ} 01^{\prime} \mathrm{N}$, $144^{\circ} 52^{\prime} \mathrm{E}$ ) in Akkeshi Bay, eastern Hokkaido, Japan.

In a time-course experiment ( 30 June), seawater was prescreened with a $94 \mu \mathrm{m}$ mesh net, poured into a 201 carboy and ${ }^{15} \mathrm{NH}_{4}{ }^{+}\left(99.0\right.$ atom\% $\left.{ }^{15} \mathrm{~N}\right)$ was added to the

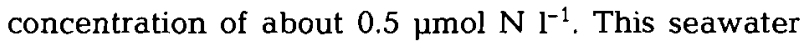
was incubated and subsamples were taken at $0,2,4$, 8 and $12 \mathrm{~h}$. In size-fraction experiments (25 May, 29 June and 24 August), seawater was prescreened with a 94 or $20 \mu \mathrm{m}$ mesh net, poured into $4 \mathrm{l}$ polycarbonate bottles and ${ }^{15} \mathrm{NH}_{4}{ }^{+}\left(99.0\right.$ atom $\left.\%{ }^{15} \mathrm{~N}\right)$ was added to the concentration of about 0.5 (25 May and 29 June) or $1 \mu \mathrm{mol} \mathrm{N} \mathrm{^{-1 }}$ (24 August). These seawaters were poured into 11 polycarbonate bottles and incubated for either 1 or $6 \mathrm{~h}$. Duplicate bottles were used for each size-fraction. The remaining seawater in the 41 polycarbonate bottles was sacrificed to time zero. In all experiments, continuous illumination was provided by fluorescent light and incubation temperature was controlled by running seawater of 2 to $3^{\circ} \mathrm{C}$ higher than the ambient temperature. The bottles were gently shaken at 0.5 to $1 \mathrm{~h}$ intervals to keep the contents well-mixed. Light intensity was measured with a quantum meter (Li-Cor). Incubation conditions are shown in Table 1. As we added a higher amount of ${ }^{15} \mathrm{NH}_{4}{ }^{+}(0.5$ to $1 \mu \mathrm{mol}$ $\mathrm{N} \mathrm{I}^{-1}$ ) compared to ambient concentrations (less than $0.1 \mu \mathrm{mol} \mathrm{N} \mathrm{^{-1 }}$ ), measured nitrogen flux would be enhanced.

At the beginning and the end of the size-fraction experiments and at each sampling point in the time-

Table 1. Dates and conditions of incubation experiments

\begin{tabular}{|lcrrr|}
\hline Date & $\begin{array}{c}\text { Incubation } \\
\text { temp. }\left({ }^{\circ} \mathrm{C}\right)\end{array}$ & $\begin{array}{c}\text { Incubation } \\
\text { time }(\mathrm{h})\end{array}$ & $\begin{array}{c}\text { Light } \\
\left(\mu \mathrm{E} \mathrm{s}^{-1} \mathrm{~m}^{-2}\right)\end{array}$ & $\begin{array}{c}\text { Type of } \\
\text { experiment }\end{array}$ \\
\hline 30 Jun & 13 & 12 & 34 & Time-course \\
25 May & 10 & 6 & 70 & Size-fraction \\
29 Jun & 13 & 6 & 34 & Size-fraction \\
24 Aug & 18 & 1 & 40 & Size-fraction \\
\hline
\end{tabular}

course experiment, seawater (250 to $500 \mathrm{ml}$ ) was filtered through a GF/F filter $(47 \mathrm{~mm})$ and this filtrate was further filtered through a $0.2 \mu \mathrm{m}$ Nuclepore filter $(47 \mathrm{~mm})$. The $0.2 \mu \mathrm{m}$ Nuclepore filtrates were frozen for later analyses in 250 or $500 \mathrm{ml}$ polyethylene bottles (for concentration of DON, nitrogen isotopic-ratios of $\mathrm{NH}_{4}{ }^{+}$and DON) and in $10 \mathrm{ml}$ test tubes (for concentration of $\mathrm{NH}_{4}{ }^{+}, \mathrm{NO}_{3}{ }^{-}, \mathrm{NO}_{2}{ }^{-}$and $\mathrm{PO}_{4}{ }^{3}-$ ). The $\mathrm{GF} / \mathrm{F}$ filter with particulate organic matter (POM) was frozen until later analysis of its nitrogen contents and nitrogen isotopic ratio. For chlorophyll a (chl a) analysis, a subsample $(50$ to $100 \mathrm{ml}$ ) was filtered through a GF/F filter (25 mm) and the filter was frozen. For bacterial counts, a subsample $(10 \mathrm{ml})$ was fixed with Formalin (final conc. $1 \%$ ) and stored at $4{ }^{\circ} \mathrm{C}$. The GF/F filters for collecting POM were precombusted at $450^{\circ} \mathrm{C}$ for $3 \mathrm{~h}$ and all bottles were acid-washed and rinsed thoroughly with distilled water prior to use. Vacuum filtration onto a GF/F filter was done at $<50 \mathrm{~mm} \mathrm{Hg}$ to minimize disruption of cells.

Chemical, isotopic and bacterial analyses. $\mathrm{NH}_{4}{ }^{+}$, $\mathrm{NO}_{3}{ }^{-}, \mathrm{NO}_{2}{ }^{-}$and $\mathrm{PO}_{4}{ }^{3-}$ concentrations were determined with a Technicon autoanalyzer (Strickland \& Parsons 1972). DON concentrations were measured by the wet oxidation method of Solórzano \& Sharp (1980). To prepare the sample for nitrogen isotopic measurements of $\mathrm{NH}_{4}{ }^{+}$, we applied the conventional steam distillation method of Bremner \& Keeney (1965). $\mathrm{NH}_{4}{ }^{+}$in a $15 \mathrm{ml}$ sample with a $1.5 \mu \mathrm{mol} \mathrm{NH}_{4}{ }^{+}$spike as carrier, was distilled and recovered in $5 \mathrm{ml}$ of $0.01 \mathrm{~N} \mathrm{H}_{2} \mathrm{SO}_{4}$. The recovered $\mathrm{NH}_{4}{ }^{+}$was concentrated to a final volume of $<1 \mathrm{ml}$ by a rotary evaporater and the concentrate was absorbed to a $\mathrm{GF} / \mathrm{F}$ filter $(25 \mathrm{~mm})$ and dried at $100^{\circ} \mathrm{C}$ for ${ }^{15} \mathrm{~N}$ analysis.

Samples for the determination of the nitrogen isotopic ratio of DON were prepared by the method described by Slawyk \& Raimbault (1995) with some modification after Hasegawa et al. (2000). We used some drops of $1.5 \mathrm{~N} \mathrm{NaOH}$ solution substituting for $\mathrm{MgO}$ to raise the $\mathrm{pH}$ to 9.5. Further, we employed vacuum evaporation $\left(50^{\circ} \mathrm{C}\right.$ ) to remove $\mathrm{NH}_{4}{ }^{+}$(Step 1: Hasegawa et al. 2000), instead of the original diffusion procedure, to save the preparation time. Briefly, a $500 \mathrm{ml}$ Pyrex bottle was capped with a silicone plug penetrated with a glass tube. The tube was then connected to an aspirator and the contents of the bottle $(250 \mathrm{ml})$ were concentrated to about $50 \mathrm{ml}$. As a result of this method, the efficiency of DIN removal was over $99 \%$. After the removal, DON was digested to $\mathrm{NO}_{3}{ }^{-}$(Step 2) and was then reduced to $\mathrm{NH}_{4}{ }^{+}$and this $\mathrm{NH}_{4}{ }^{+}$was recovered into $\mathrm{H}_{2} \mathrm{SO}_{4}$ soaked in a $25 \mathrm{~mm} \mathrm{GF} / \mathrm{F}$ filter (Step 3).

To examine the blank, and the recovery of DON, we used filtered seawater (aged-surface water of oligotrophic western Pacific: DON $4.18 \mu \mathrm{M}$, DIN $<0.05 \mu \mathrm{M}$ ) 
and ${ }^{15} \mathrm{NO}_{3}{ }^{-},{ }^{15} \mathrm{~N}$-glycine and ${ }^{15} \mathrm{~N}$-urea $(99.1,99.0$, 99.7 atom $\%{ }^{15} \mathrm{~N}$, respectively) (Hasegawa et al. 2000). First, we checked the procedure blank and the reagent blank by using a ${ }^{15} \mathrm{NO}_{3}{ }^{-}$isotope dilution method. After the seawater was processed through Steps 1 and 2, ${ }^{15} \mathrm{NO}_{3}{ }^{-}(2 \mu \mathrm{mol})$ was added into the Pyrex bottle and then was proceeded to Step 3 . From the measured ${ }^{15} \mathrm{~N}$ atom $\%$ value and added amount of ${ }^{15} \mathrm{NO}_{3}{ }^{-}$, we calculated the amount of $\mathrm{NO}_{3}{ }^{-}$in the bottle after DON digestion assuming ${ }^{15} \mathrm{~N}$ atom\% in DON of the seawater as $0.366 \%$. The calculated amounts $(5.04 \pm 0.10 \mu \mathrm{M}, \mathrm{n}=$ 3) should correspond to DON in the seawater, including the blank. Since we used aged seawater which contained little labile DON, the loss of DON during isolation was negligible. Thus, we defined the total blank as the difference $(0.86 \mu \mathrm{M})$ between DON amount $(4.18 \mu \mathrm{M})$ and the calculated $\mathrm{NO}_{3}{ }^{-}$in the bottle $(5.04 \mu \mathrm{M})$. In all incubation experiments, total blank was less than $20 \%$ of DON concentrations and the variation of reagent blank was small (within $15 \%$ ). Thus, we used the same blank value for the calculation in all experiments.

Then, to test the recovery of known organic compounds, we added ${ }^{15} \mathrm{~N}$-glycine or ${ }^{15} \mathrm{~N}$-urea into the aliquots of the seawater and performed Steps 1 to 3 . The measured ${ }^{15} \mathrm{~N}$ atom\% agreed well with the calculated ${ }^{15} \mathrm{~N}$ atom $\%$ which was obtained from the additional amount of ${ }^{15} \mathrm{~N}$ labeled organic compounds and the amount of DON in the seawater (Hasegawa et al. 2000). We estimated that more than $95 \%$ of ${ }^{15} \mathrm{~N}$ labeled organic compounds were converted into $\mathrm{NH}_{4}{ }^{+}$ in our method, while the final recovery of nitrogen as a whole was seldom higher than $80 \%$. These results strongly suggest that most of the DON in the seawater and the ${ }^{15} \mathrm{~N}$ labeled organic compounds were not lost during isolation, and that the low recovery of DON is primarily a consequence of low $\mathrm{NH}_{4}{ }^{+}$transfer efficiency to the GF/F filter. Therefore we used ${ }^{15} \mathrm{~N}$ atom\% of nitrogen recovered into the GF/F filter as atom $\%$ for the whole DON.

The nitrogen isotopic ratio of DON, PON and $\mathrm{NH}_{4}{ }^{+}$, and organic nitrogen contents of POM were analyzed using a continuous flow mass spectrometer (Tracermass, Europa Scientific) equipped with a $\mathrm{CN}$ analyzer (Roboprep-CN, Europa Scientific) (Kanda et al. 1998). Sodium L-glutamate monohydrate $\left(0.366\right.$ atom $\left.\%{ }^{15} \mathrm{~N}\right)$ and glycine ( 1.66 to 4.51 atom\% ${ }^{15} \mathrm{~N}$ ) were used as the standard samples. Standard deviation for atom\% of L-glutamate monohydrate $(1 \mu \mathrm{mol} \mathrm{N})$ is smaller than $0.0012(\mathbf{n}=6)$. Chl a was determined by the fluorometric method of Strickland \& Parsons (1972) as modified by Suzuki \& Ishimaru (1990), using a Turner Designs fluorometer. Bacteria were counted by epifluorescence microscopy after DAPI staining (Porter \& Feig 1980). Growth rates of bacteria were estimated by counting cell numbers at the beginning and the end of incubation, and assuming their exponential growth.

Calculation. Uptake rates of $\mathrm{NH}_{4}{ }^{+}$were estimated after Glibert et al. (1982). When $\mathrm{NO}_{3}{ }^{-}$was detectable (29 June), the uptake rate of $\mathrm{NO}_{3}{ }^{-}$was estimated from change in concentration.

${ }^{15} \mathrm{~N}$ atom\% excess in each fraction was denoted as atom\% of each fraction minus natural abundance of ${ }^{15} \mathrm{~N}(0.366 \%)$.

PER was calculated as follows

$$
\text { PER }=\frac{\text { excessDO }{ }^{15} \mathrm{~N} \times 100}{\text { excessDO }{ }^{15} \mathrm{~N}+\operatorname{excessPO^{15}N}}
$$

where excessDO ${ }^{15} \mathrm{~N}$ and excessPO ${ }^{15} \mathrm{~N}$ are concentrations of excess ${ }^{15} \mathrm{~N}$ (nM) defined as follows

$$
\begin{aligned}
\text { excessDO } & 15 \mathrm{~N}= \\
& { }^{15} \mathrm{~N} \text { atom } \% \text { excess in DON } \\
& \times \text { concentration of DON } / 100
\end{aligned}
$$

and

$$
\begin{aligned}
\text { excess } \mathrm{PO}^{15} \mathrm{~N}= & { }^{15} \mathrm{~N} \text { atom } \% \text { excess in PON } \\
& \times \text { concentration of PON } / 100
\end{aligned}
$$

Since we used ${ }^{15} \mathrm{NH}_{4}{ }^{+}$as a tracer, PER is affected primarily by metabolism of dominated $\mathrm{NH}_{4}{ }^{+}$utilizing organisms, i.e., phytoplankton in our experiments, but possibly also affected by other organisms such as bacteria and micrograzers.

\section{RESULTS AND DISCUSSION}

\section{Time-course experiment}

During the $12 \mathrm{~h}$ of incubation, concentrations of $\mathrm{NH}_{4}{ }^{+}$decreased from 0.52 to $0.23 \mu \mathrm{M}$, whereas concentrations of $\mathrm{PO}_{4}{ }^{3-}$ and DON remained almost unchanged and chl $a$ increased slightly (Table 2 ). Recovery of ${ }^{15} \mathrm{~N}$ (sum of excess ${ }^{15} \mathrm{~N}$ in $\mathrm{NH}_{4}{ }^{+}$, PON and DON) decreased with time, and was $82 \%$ at the end of incubation (Fig. 1, Table 3). Although we did not measure ${ }^{15} \mathrm{~N}$ in $\mathrm{NO}_{3}{ }^{-}$and $\mathrm{NO}_{2}{ }^{-}$, significant transfer of ${ }^{15} \mathrm{~N}$ into those fractions by nitrification was doubtful, since concentrations of $\mathrm{NO}_{3}{ }^{-}$and $\mathrm{NO}_{2}{ }^{-}$during the incubation period remained under the detection limit $(<0.05 \mu \mathrm{M})$. ${ }^{15} \mathrm{~N}$ might be lost through direct adsorption of ${ }^{15} \mathrm{NH}_{4}{ }^{+}$ on the incubation bottle and/or uptake of ${ }^{15} \mathrm{NH}_{4}{ }^{+}$by bacteria attached to the bottle wall (Slawyk \& Raimbault 1995).

The ${ }^{15} \mathrm{~N}$ tracer in PON, which is the source of $D \mathrm{O}^{15} \mathrm{~N}$, increased almost constantly throughout the $12 \mathrm{~h}$ of incubation, while ${ }^{15} \mathrm{~N}$ in the DON pool increased as a hyperbolic function with time of the incubation (Fig. 1). Lancelot (1984) reported similar trends for the extracellular release of $\mathrm{DO}^{14} \mathrm{C}$ by natural planktonic assemblages in coastal water. Using size-fractionated seawa- 

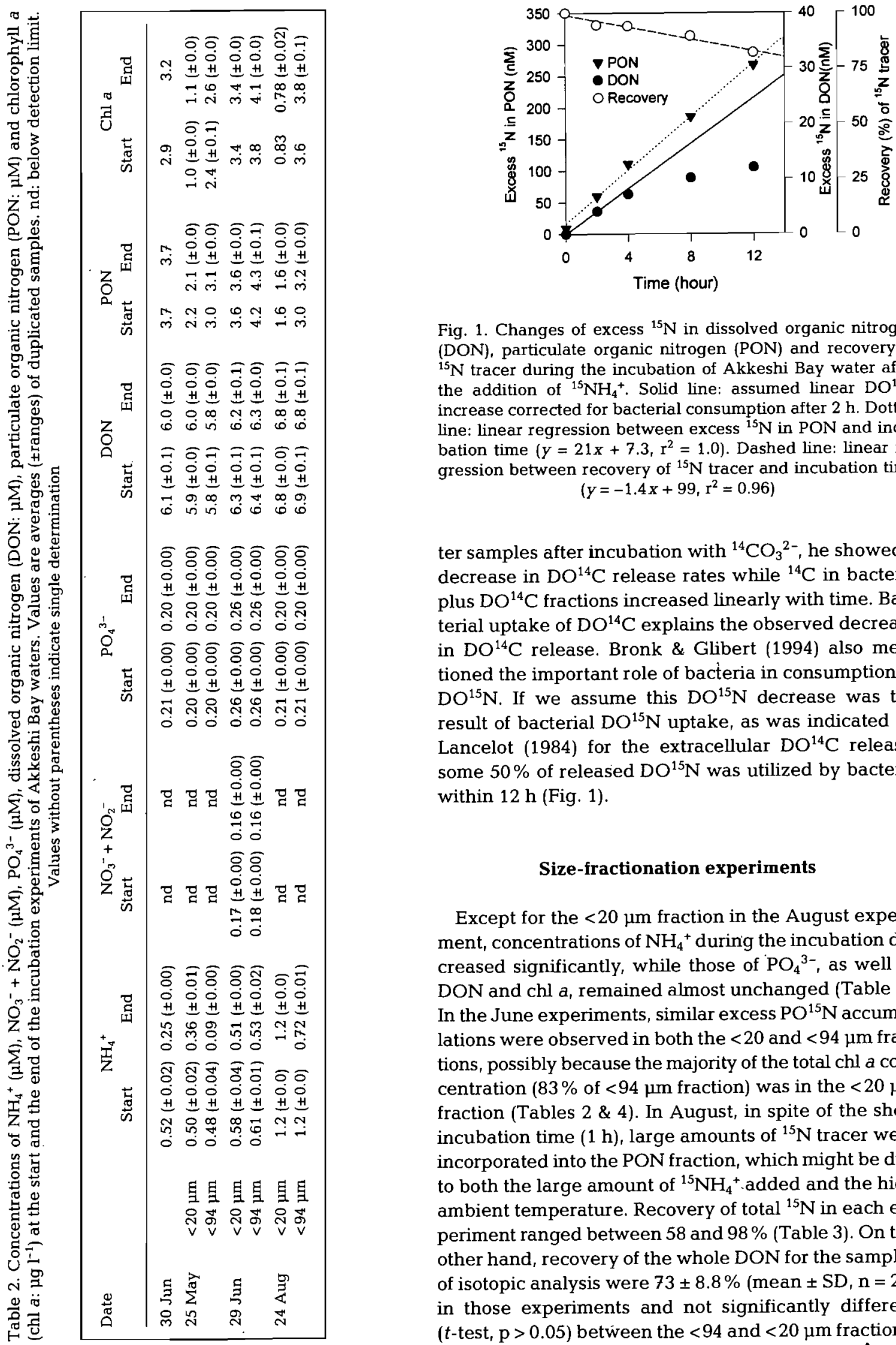

Fig. 1. Changes of excess ${ }^{15} \mathrm{~N}$ in dissolved organic nitrogen (DON), particulate organic nitrogen (PON) and recovery of ${ }^{15} \mathrm{~N}$ tracer during the incubation of Akkeshi Bay water after the addition of ${ }^{15} \mathrm{NH}_{4}^{+}$. Solid line: assumed linear $D \mathrm{D}^{15} \mathrm{~N}$ increase corrected for bacterial consumption after $2 \mathrm{~h}$. Dotted line: linear regression between excess ${ }^{15} \mathrm{~N}$ in PON and incubation time $\left(y=21 x+7.3, r^{2}=1.0\right)$. Dashed line: linear regression between recovery of ${ }^{15} \mathrm{~N}$ tracer and incubation time $\left(y=-1.4 x+99, r^{2}=0.96\right)$

ter samples after incubation with ${ }^{14} \mathrm{CO}_{3}{ }^{2-}$, he showed a decrease in $\mathrm{DO}^{14} \mathrm{C}$ release rates while ${ }^{14} \mathrm{C}$ in bacteria plus $\mathrm{DO}^{14} \mathrm{C}$ fractions increased linearly with time. Bacterial uptake of $\mathrm{DO}^{14} \mathrm{C}$ explains the observed decrease in $\mathrm{DO}^{14} \mathrm{C}$ release. Bronk \& Glibert (1994) also mentioned the important role of bacteria in consumption of $D O^{15} \mathrm{~N}$. If we assume this $D \mathrm{O}^{15} \mathrm{~N}$ decrease was the result of bacterial $\mathrm{DO}^{15} \mathrm{~N}$ uptake, as was indicated by Lancelot $(1984)$ for the extracellular $D \mathrm{O}^{14} \mathrm{C}$ release, some $50 \%$ of released $D^{15} \mathrm{~N}$ was utilized by bacteria within $12 \mathrm{~h}$ (Fig. 1).

\section{Size-fractionation experiments}

Except for the $<20 \mu \mathrm{m}$ fraction in the August experiment, concentrations of $\mathrm{NH}_{4}{ }^{+}$during the incubation decreased significantly, while those of $\mathrm{PO}_{4}{ }^{3-}$, as well as DON and chl $a$, remained almost unchanged (Table 2). In the June experiments, similar excess $\mathrm{PO}^{15} \mathrm{~N}$ accumulations were observed in both the $<20$ and $<94 \mu \mathrm{m}$ fractions, possibly because the majority of the total chl a concentration ( $83 \%$ of $<94 \mu \mathrm{m}$ fraction) was in the $<20 \mu \mathrm{m}$ fraction (Tables $2 \& 4$ ). In August, in spite of the short incubation time $(1 \mathrm{~h})$, large amounts of ${ }^{15} \mathrm{~N}$ tracer were incorporated into the PON fraction, which might be due to both the large amount of ${ }^{15} \mathrm{NH}_{4}{ }^{+}$.added and the high ambient temperature. Recovery of total ${ }^{15} \mathrm{~N}$ in each experiment ranged between 58 and $98 \%$ (Table 3 ). On the other hand, recovery of the whole DON for the samples of isotopic analysis were $73 \pm 8.8 \%$ (mean $\pm S D, n=26$ ) in those experiments and not significantly different ( $t$-test, $p>0.05$ ) between the $<94$ and $<20 \mu \mathrm{m}$ fractions. 
Table 3. ${ }^{15} \mathrm{~N}$ atom $\%$ in $\mathrm{NH}_{4}{ }^{+}$, particulate organic nitrogen (PON), dissolved organic nitrogen (DON) and recovery (\%) of ${ }^{15} \mathrm{~N}$ tracer. Values are averages ( \pm ranges) of duplicated samples. Values without parentheses indicate single determination

\begin{tabular}{|c|c|c|c|c|c|c|c|}
\hline \multirow[t]{2}{*}{ Date } & & \multicolumn{2}{|c|}{$\mathrm{NH}_{4}^{+}$} & \multicolumn{2}{|c|}{ PON } & \multirow{2}{*}{$\begin{array}{l}\text { DON }^{\mathrm{a}} \\
\text { End }\end{array}$} & \multirow{2}{*}{$\begin{array}{c}\text { Recovery } \\
(\%)\end{array}$} \\
\hline & & Start & End & Start & End & & \\
\hline $30 \mathrm{Jun}$ & & 91.3 & 47.1 & 0.613 & 7.61 & 0.566 & 81.9 \\
\hline 25 May & $\begin{array}{l}<20 \mu \mathrm{m} \\
<94 \mu \mathrm{m}\end{array}$ & $\begin{array}{r}99.0 \\
-99.0\end{array}$ & $\begin{array}{l}98.1( \pm 0.7) \\
58.7( \pm 4.3)\end{array}$ & $\begin{array}{l}0.558 \\
0.864\end{array}$ & $\begin{array}{l}4.95( \pm 0.02) \\
7.63( \pm 0.01)\end{array}$ & $\begin{array}{l}0.477( \pm 0.001) \\
0.510( \pm 0.004)\end{array}$ & $\begin{array}{l}91.4( \pm 0.3) \\
57.5( \pm 0.8)\end{array}$ \\
\hline 29 Jun & $\begin{array}{l}<20 \mu \mathrm{m} \\
<94 \mu \mathrm{m}\end{array}$ & $\begin{array}{l}80.8 \\
77.3\end{array}$ & $\begin{array}{l}69.2( \pm 1.0) \\
60.4( \pm 1.5)\end{array}$ & $\begin{array}{l}0.444 \\
0.423\end{array}$ & $\begin{array}{l}3.27( \pm 0.04) \\
3.27( \pm 0.05)\end{array}$ & $\begin{array}{l}0.438( \pm 0.016) \\
0.469( \pm 0.006)\end{array}$ & $\begin{array}{l}97.9( \pm 1.6) \\
94.6( \pm 1.4)\end{array}$ \\
\hline 24 Aug & $\begin{array}{l}<20 \mu \mathrm{m} \\
<94 \mu \mathrm{m}\end{array}$ & $\begin{array}{l}99.0 \\
97.8\end{array}$ & $\begin{array}{l}85.0 \\
94.2\end{array}$ & $\begin{array}{l}1.02 \\
1.59\end{array}$ & $\begin{array}{l}2.99( \pm 0.23) \\
8.80( \pm 0.13)\end{array}$ & $\begin{array}{l}0.430( \pm 0.026) \\
0.478( \pm 0.002)\end{array}$ & $\begin{array}{l}86.3( \pm 0.4) \\
82.3( \pm 0.3)\end{array}$ \\
\hline
\end{tabular}

Table 4. Accumulation of excess ${ }^{15} \mathrm{~N}$ concentrations in particulate organic nitrogen (PON; $\mathrm{nM}$ ) and dissolved organic nitrogen $\left(D_{0 N} ; \mathrm{nM}\right)$ and percent extracellular release (PER) during the size-fractionated incubations of Akkeshi Bay waters. Values are averages (tranges) of duplicated samples

\begin{tabular}{|ccccccc|}
\hline & \multicolumn{2}{c}{$25 \mathrm{May}$} & \multicolumn{2}{c}{$29 \mathrm{Jun}$} & \multicolumn{2}{c}{$24 \mathrm{Aug}$} \\
& $<20 \mu \mathrm{m}$ & $<94 \mu \mathrm{m}$ & $<20 \mu \mathrm{m}$ & $<94 \mu \mathrm{m}$ & $<20 \mu \mathrm{m}$ \\
\hline PON & $95( \pm 1.3)$ & $222( \pm 0.17)$ & $103( \pm 1.0)$ & $125( \pm 4.2)$ & $41( \pm 4.2)$ & $266( \pm 11)$ \\
DON & $6.6( \pm 0.07)$ & $8.3( \pm 0.32)$ & $4.5( \pm 0.92)$ & $6.5( \pm 0.40)$ & $4.4( \pm 1.8)$ & $7.6( \pm 0.03)$ \\
PER & $6.5( \pm 0.02)$ & $3.6( \pm 0.13)$ & $4.1( \pm 0.77)$ & $4.9( \pm 0.44)$ & $9.9( \pm 4.5)$ & $2.7( \pm 0.12)$ \\
\hline
\end{tabular}

PER in the $<20 \mu \mathrm{m}$ fraction was significantly higher than that in the $<94 \mu \mathrm{m}$ fraction, except for in the 29 June experiments, where the majority of ${ }^{15} \mathrm{NH}_{4}{ }^{+}$uptake occurred in the $<20 \mu \mathrm{m}$ fraction (Table 4). These results indicated that removal of the larger plankton modifies the balance between $\mathrm{PO}^{15} \mathrm{~N}$ production and subsequent $D \mathrm{DO}^{15} \mathrm{~N}$ release by the community. There are 2 possible mechanisms to explain the above change, i.e., modification of food chain interactions through removing $>20 \mu \mathrm{m}$ micrograzers and efficient $D \mathrm{O}^{15} \mathrm{~N}$ release by smaller phytoplankton.

Although the composition of micrograzers could possibly change, growth rates of bacteria were not significantly different in the above 3 experiments ( $t$-test, $p>0.05$ ) between the $<20$ and $<94 \mu \mathrm{m}$ fractions. This suggests that grazing pressure on bacteria was rather similar in both fractions and thus bacterial consumption of $\mathrm{DO}^{15} \mathrm{~N}$ and ${ }^{15} \mathrm{NH}_{4}{ }^{+}$was not significantly different. Furthermore, since we used a $0.2 \mu \mathrm{m}$ Nuclepore filter, which retains bacteria almost completely, to prepare DON samples, bacterial ${ }^{15} \mathrm{~N}$ was not included in the measured $\mathrm{DO}^{15} \mathrm{~N}$. Therefore, metabolism of bacteria cannot adequately explain the efficient $D O^{15} \mathrm{~N}$ release in the $<20 \mu \mathrm{m}$ fraction.

DO ${ }^{15} \mathrm{~N}$ release by micrograzers might have been low in our experiment because we added ${ }^{15} \mathrm{NH}_{4}{ }^{+}$at the start of incubation, and ${ }^{15} \mathrm{~N}$ label in their prey was inadequate. For example, if we assume that micrograzer consumption on phytoplankton is in balance with phytoplankton production in terms of nitrogen, clearance rate $\left(\mathrm{CR}_{i} \mathrm{ml} \mathrm{h}^{-1}\right)$ of micrograzers was estimated as follows

$$
\mathrm{CR}=\frac{\text { Ingested } \mathrm{PON} \times \mathrm{Vol}}{\text { Phyto } \mathrm{N} \times \text { time }}=\frac{\text { Uptake } \mathrm{IN} \times \mathrm{Vol}}{\text { Phyto } \mathrm{N} \times \text { time }}
$$

where Ingested PON and Uptake IN are ingested nitrogen by micrograzers and nitrogen production in phytoplankton during the incubation $(\mu \mathrm{M})$, respectively. Phyto $\mathrm{N}$ is phytoplankton nitrogen ( $\mu \mathrm{M})$, and Vol and time are incubation volume (l) and incubation time (h), respectively. For the $<20 \mu \mathrm{m}$ fraction, chl $a$ concentrations during the incubation were almost constant, in accordance with the assumption of the balance between consumption and production. Phyto $\mathrm{N}$ was calculated from initial chl a concentrations (Table 2), assuming a nitrogen ( $\mu \mathrm{mol}) / \mathrm{chl}$ a $(\mu \mathrm{g})$ ratio of 0.51 (Redfield et al. 1963, Li et al. 1993). Ingested $\mathrm{PO}^{15} \mathrm{~N}$ (nM) by micrograzers was estimated as

$$
\text { Ingested } \mathrm{PO}^{15} \mathrm{~N}=\frac{\mathrm{CR} \times \text { Ave } \mathrm{PO}^{15} \mathrm{~N} \times \text { time }}{\mathrm{Vol}}
$$

where Ave $P O^{15} \mathrm{~N}$ is average excess $\mathrm{PO}^{15} \mathrm{~N}$ concentration (nM) during the incubation, obtained by assuming 
linear increase in excess $\mathrm{PO}^{15} \mathrm{~N}$ concentrations within incubation time. Due to the assumption that production and consumption are in balance, phytoplankton nitrogen is constant during the incubation. Micrograzers release some $30 \%$ of their prey organic carbon as DOC (Strom et al. 1997). If we also assume a $30 \%$ release of ingested organic $\mathrm{N}$ in prey as DON, calculated $\mathrm{DO}^{15} \mathrm{~N}$ release by micrograzers in the $<20 \mu \mathrm{m}$ fraction were 0.50 to $2.5 \mathrm{nM}$ during the incubation, which accounted for only 11 to $38 \%$ of the observed total $D O^{15} \mathrm{~N}$ release in this fraction. Our estimations of $D O^{15} \mathrm{~N}$ release by micrograzers were overestimated because we did not consider possible bacterial consumption of $\mathrm{DO}^{15} \mathrm{~N}$ in this calculation (see above). Also, many studies showed that micrograzer consumption on phytoplankton was usually lower than production of phytoplankton (Landry \& Hassett 1982, Paranjape 1987, Gifford 1988). Therefore, grazing of micrograzers in the $<20 \mu \mathrm{m}$ fraction was untenable to explain the observed PER in this fraction.

If our maximum values for $\mathrm{DO}^{15} \mathrm{~N}$ release by $<20 \mu \mathrm{m}$ micrograzers are adopted (from which we derived a minimum estimation of $<20 \mu \mathrm{m}$ phytoplankton release), PER caused by phytoplankton in the $<20 \mu \mathrm{m}$ fraction in May and August are 4.0 and $8.6 \%$, respectively. Even if the observed PER of the $<94 \mu \mathrm{m}$ fraction was caused only by phytoplankton (from which we derived maximum estimation of phytoplankton release), the PER of the $<20 \mu \mathrm{m}$ fraction, which in May and August was higher than that of the $<94 \mu \mathrm{m}$ fraction (Table 4). This suggests that smaller phytoplankton release $\mathrm{DO}^{15} \mathrm{~N}$ more efficiently than larger ones. Bjørnsen (1988) proposed that release of DOM is passive permeation through the cell membrane. If so, efficient DON release by smaller phytoplankton can be explained because smaller phytoplankton have a larger surface area per unit volume compared to larger ones.

\section{PER of planktonic assemblages}

We observed that PER values ranged from 2.7 to $4.9 \%$ ( $<94 \mu \mathrm{m}$ fraction) in coastal waters of a subarctic region. A wide range of $\mathrm{PER}$ (from undetectable to over $90 \%$ ) was reported from various field work (Bronk et al. 1994, Slawyk \& Raimbault 1995, Slawyk et al. 1998, Bronk \& Ward 1999). We do not know what caused such diversity in PER. Baines \& Pace (1991) denoted that for carbon, $13 \%$ is the average PER among various environmental conditions. Very high PER for carbon is associated with extreme irradiances (Zlotink \& Dubinsky 1989) and with nutrient depletion (Lancelot 1983).

As for the dissolved organic carbon release by phytoplankton, Fogg (1983) proposed that an overflow mechanism occurs when carbon fixation by phytoplankton exceeded their growth. However, it is unlikely that the same mechanism applies for the DON release because growth of marine phytoplankton is generally considered as nitrogen limited (McCarthy 1980, Glibert 1988). This implies that PER for nitrogen is rather smaller than that for carbon. If we consider that the average PER for carbon was $13 \%$, our estimation for PER of DON might be more general for healthy phytoplankton.

If all the ${ }^{15} \mathrm{~N}$ absent was lost from the DON pool during isolation, our conclusions should change drastically. In the May and August experiments, PER for the $<94 \mu \mathrm{m}$ fraction would be larger than $44 \%$, and in May PER for the $<94 \mu \mathrm{m}$ fraction would be larger than that for the $<20 \mu \mathrm{m}$ fraction. If that was the case, we would have lost 87 to $97 \%$ of $\mathrm{DO}^{15} \mathrm{~N}$ for both size-fractions in those experiments. However, this is highly untenable from the fact (1) that over $95 \%$ of ${ }^{15} \mathrm{~N}$ labeled glycine and urea remained after isolation and reduced to $\mathrm{NH}_{4}{ }^{+}$ and (2) that final recovery of DON as a whole was $73 \%$ on average. Therefore, the primary source of missing ${ }^{15} \mathrm{~N}$ would be explained by other mechanisms rather than ${ }^{15} \mathrm{~N}$ loss from some labile DON pool during isolation.

In this study, we showed significant release of $\mathrm{DO}^{15} \mathrm{~N}$ from phytoplankton while production of phytoplankton tends to be limited by nitrogen in marine environments (McCarthy 1980, Glibert 1988). If the release of DON is a passive permeation of cellular nitrogen metabolites as we speculated, it is an inevitable loss for phytoplankton. However, this apparently wasteful nature of phytoplankton in terms of nitrogen (i.e., release of their gained nitrogen as DON) was partially compensated by bacterial utilization coupled tightly with the release process, that is, nitrogenous compounds are kept efficiently within the biota in this environment.

Our evaluation of $\mathrm{DO}^{15} \mathrm{~N}$ release mediated by micrograzers obviously underestimated the actual rate of their DON release, because of inadequate ${ }^{15} \mathrm{~N}$ label in their prey in our experimental conditions. In addition, macrozooplankton also contributed to DON release (Lampert 1978, Strom et al. 1997). Although $\mathrm{DO}^{15} \mathrm{~N}$ release and consumption were well coupled, total DON release by phytoplankton and zooplankton might have exceeded its consumption by bacteria in some cases. In fact, accumulation of DON was observed at the surface layer of the Akkeshi Bay from March to August (Hasegawa unpubl.), and Williams (1995) also suggested that DON might accumulate during the blooming season. This 'deposit' of DON would become an important nitrogen source in stratified and $\mathrm{N}$-impoverished seawater after the blooming season. 
Acknowledgements. We thank M. Moroi, S. Hamano and H. Nakamura of the Akkeshi Biological Station, Hokkaido University, for logistic support. We also thank T. Miyajima for his valuable comments.

\section{LITERATURE CITED}

Axler RP, Reuter JE (1986) A simple method for estimating the ${ }^{25} \mathrm{~N}$ content of dissolved organic matter $\left(\mathrm{DO}^{15} \mathrm{~N}\right)$ in $\mathrm{N}$ cycling studies. Can J Fish Aquat Sci 43:130-133

Baines SB, Pace ML (1991) The production of dissolved organic matter by phytoplankton and its importance to bacteria: patterns across marine and freshwater systems. Limnol Oceanogr 36:1078-1090

Bjørnsen PK (1988) Phytoplankton exudation of organic matter: why do healthy cells do it? Limnol Oceanogr 33: 151-154

Bratbak G, Heldal M, Thingstad TF, Riemann B, Haslund OH (1992) Incorporation of viruses into the budget of microbial C-transfer. A first approach. Mar Ecol Prog Ser 83: 273-280

Bremner JM, Keeney DR (1965) Steam distillation methods for determination of ammonium, nitrate and nitrite. Anal Chim Acta 32:485-495

Bronk DA, Glibert PM (1991) A ${ }^{15} \mathrm{~N}$ tracer method for the measurement of dissolved organic nitrogen release by phytoplankton. Mar Ecol Prog Ser 77:171-182

Bronk DA, Glibert PM (1993a) Application of a ${ }^{15} \mathrm{~N}$ tracer method to the study of dissolved organic nitrogen uptake during spring and summer in Chesapeake Bay. Mar Biol 115:501-508

Bronk DA, Glibert PM (1993b) Contrasting patterns of dissolved organic nitrogen release by two size-fractions of estuarine plankton during a period of rapid $\mathrm{NH}_{4}{ }^{+}$consumption and $\mathrm{NO}_{2}{ }^{+}$production. Mar Ecol Prog Ser 96 291-299

Bronk DA, Glibert PM (1994) The fate of the missing ${ }^{15} \mathrm{~N}$ differs among marine systems. Limnol Oceanogr 39:189-195

Bronk DA. Ward BB (1999) Gross and net nitrogen uptake and DON release in the euphotic zone of Monterey Bay, California. Limnol Oceanogr 44:573-585

Bronk DA, Glibert PM, Ward BB (1994) Nitrogen uptake, dissolved organic nitrogen release, and new production. Science 265:1843-1846

Fogg GE (1983) The ecological significance of extracellular products of phytoplankton photosynthesis. Bot Mar 26 3-14

Gifford DJ (1988) Impact of grazing by microzooplankton in the Northwest Arm of Halifax Harbour, Nova Scotia. Mar Ecol Prog Ser 47:249-258

Glibert PM (1988) Primary production and pelagic nitrogen cycling. In: Blackburn TH, Sørensen J (eds) Nitrogen cycling in coastal marine environments. John Wiley \& Sons Ltd, Chichester, p 3-31

Glibert PM, Lipschultz F, McCarthy JJ, Altabet MA (1982) Isotope dilution models of uptake and remineralization of ammonium by marine plankton. Limnol Oceanogr 27 : $639-650$

Hasegawa T, Koike I, Mukai H (2000) Dissolved organic nitrogen dynamics in coastal waters and the effect of copepods. J Exp Mar Biol Ecol 244:219-238

Jackson GA, Williams PM (1985) Importance of dissolved organic nitrogen and phosphorus to biological nutrient cycling. Deep-Sea Res 32:223-235

Kanda J, Sada K, Koike I, Yokouchi K (1998) Application of an automated carbon-nitrogen analyzer for elemental and isotopic analysis of samples of retained on glass-fiber filters. Int J Environ Anal Chem 72:163-167

Lampert W (1978) Release of dissolved organic carbon by grazing zooplankton. Limnol Oceanogr 23:831-834

Lancelot C (1983) Factors affecting phytoplankton extracellular release in the Southern Bight of the North Sea. Mar Ecol Prog Ser 12:115-121

Lancelot C (1984) Extracellular release of small and large molecules by phytoplankton in the southern bight of the North Sea. Estuar Coast Shelf Sci 18:65-77

Landry MR, Hassett RP (1982) Estimating the grazing impact of marine micro-zooplankton. Mar Biol 67:283-288

Li WKW, Dickie PM, Harrison WG, Irwin BD (1993) Biomass and production of bacteria and phytoplankton during the spring bloom in the western North Atlantic Ocean. DeepSea Res 40:307-327

Mague TH, Friberg E, Hughes DJ, Morris 1 (1980) Extracellular release of carbon by marine phytoplankton; a physiological approach. Limnol Oceanogr 25:262-279

McCarthy (1980) Nitrogen and phytoplankton ecology. In: Morris I (ed) The physiological ecology of phytoplankton. Blackwell Scientific Publications, Oxford, p 191-233

Nagata T, Kirchman DC (1991) Release of dissolved free and combined amino acids by bactivorous marine flagellates. Limnol Oceanogr 36:433-443

Paranjape MA (1987) Grazing by microzooplankton in the eastern Canadian arctic in summer 1983. Mar Ecol Prog Ser 40:239-246

Porter KG, Feig YS (1980) The use of DAPl for identifying and counting aquatic microflora. Limnol Oceanogr 25:943-948

Redfield AC, Ketchum BH, Richards FA (1963) The influence of organisms on the composition of seawater. In: Hill MN (ed) The sea. Wiley-Interscience, New York, p 26-77

Sharp JH (1983) The distributions of inorganic nitrogen and dissolved and particulate organic nitrogen in the sea. In: Carpenter EJ, Capone DG (eds) Nitrogen in the marine environment. Academic Press, New York, p 1-35

Slawyk G, Raimbault P (1995) Simple procedure for simultaneous recovery of dissolved inorganic and organic nitrogen in ${ }^{15} \mathrm{~N}$-tracer experiments and improving the isotopic mass balance. Mar Ecol Prog Ser 124:289-299

Slawyk G, Raimbault P, Garcia N (1998) Measuring gross uptake of ${ }^{15} \mathrm{~N}$-labeled nitrogen by marine phytoplankton without particulate matter collection: evidence of $l o w{ }^{15} \mathrm{~N}$ losses to the dissolved organic nitrogen pool. Limnol Oceanogr 43:1734-1739

Solórzano L, Sharp JH (1980) Determination of total dissolved nitrogen in natural waters. Limnol Oceanogr 25:751-754

Strickland JDH, Parsons TR (1972) A practical handbook of seawater analysis. Bull Fish Res Board Can 167

Strom SL, Benner R, Dagg MJ (1997) Planktonic grazers are a potentially important source of marine dissolved organic carbon. Limnol Oceanogr 42:1364-1374

Suzuki R, Ishimaru T (1990) An improved method for the determination of phytoplankton chlorophyll using $\mathrm{N}, \mathrm{N}$ dimethylformamide. J Oceanogr Soc Jpn 46:143-194

Tupas L, Koike I (1991) Simultaneous uptake and regeneration of ammonium by mixed assemblages of heterotrophic marine bacteria. Mar Ecol Prog Ser 70:273-282

Williams PJleB (1995) Evidence for the seasonal accumulation of carbon-rich dissolved organic material, its scale in comparison with changes in particulate material and the consequential effect on net $\mathrm{C} / \mathrm{N}$ assimilation ratios. Mar Chem 51:17-29

Zlotnik I, Dubinsky Z (1989) The effect of light and temperature on DOC excretion by phytoplankton. Limnol Oceanogr 34:831-839 